Сильченко

Владислав Юрьевич,

ассистент кафедры

гражданского процесса

Уральского государственного

юридического университета

vladsil950िgmail.com

DOI: $10.18572 / 1812-383 X-2020-11-55-57$

\title{
Групповое производство
}

\section{и утрата права}

\section{на самостоятельный иск в арбитражном процессе}

В статье приводится оценка состоявшейся реформы группового производства в цивилистическом процессе России. Автором критикуются нормы Арбитражного процессуального кодекса Российской Федерации, в силу которых член группы, отказавшийся от участия в групповом производстве, а также третье лицо, заявляющее самостоятельные требования относительно предмета спора в групповом производстве, утрачивают возможность обратиться в суд с самостоятельным иском по требованию, с которым они могли бы вступить в групповое производство.

Ключевые слова: арбитражный процесс, групповое производство, групповой иск, процессуальная реформа, иск, право на иск.

Class Proceedings and Loss of the Right to a Separate Claim in an Arbitration Procedure

Silchenko Vladislav Yu.

Teaching Assistant of the Department of Civil Procedure of the Ural State Law University

The article provides an assessment of the reform of group production in the civil process of Russia. The author criticizes the norms of the Arbitration Procedural Code of the Russian Federation, by virtue of which a member of a group who refused to participate in a group proceeding, as well as a third party who claims independent claims regarding the subject of a dispute in a group proceeding, lose the opportunity to go to court with an independent claim at the request with which they could enter into group proceeding.

Keywords: commercial procedure, group proceedings, class actions, reform of civil process, action, right of action. 